\title{
Kompetisi beberapa jenis gulma terhadap pertumbuhan awal beberapa varietas tanaman tebu (Saccharum officinarum L.)
}

\author{
Competition of weeds types to the initial growth of several sugarcane varieties \\ (Saccharum officinarum L.)
}

\section{Dentin Queentiara Moelyaandani ${ }^{1}$ dan Setiyono ${ }^{1 *}$}

Program Studi Agroteknologi, Fakultas Pertanian, Universitas Jember, Jl. Kalimantan 37 Kampus Tegalboto, Jember 68121 Jawa Timur Indonesia

\section{INFORMASI ARTIKEL}

\author{
*Korespondensi: \\ Setiyono \\ setiyono.faperta@unej.ac.id
}

Informasi proses: Received: 12 December 2019 Accepted: 10 Januari 2020 Published: 15 Januari 2020

\section{Cara sitasi:}

Moelyaandani DQ and Setiyono (2020). Kompetisi beberapa jenis gulma terhadap pertumbuhan awal beberapa varietas tanaman tebu (Saccharum officinarum L.). Jurnal Proteksi Tanaman Tropis 1(1): 21-26

DOI:

\begin{abstract}
Sugarcane (Saccharum officinarum L.) is a sugar-producing plant and is a food commodity that is needed by the people of Indonesia. National sugar demands are increasing every year. The low productivity of sugarcane is due to the competition of weeds which can reduce sugarcane production. To achieve high productivity, it is necessary to pay attention to the varieties used because they require certain conditions in their management. The purpose of this study was to determine the effect of varieties and types of weeds on the initial growth of sugarcane. The study was conducted from September 2018 to December 2018. The study used factorial Randomized Block Design (RBD) with two factors and four replications. The first factor consists of 4 sugarcane varieties, namely: Bululawang (V1), Red HW (V2), VMC (V3) and PS 862 (V4). The second factor type of weed consists of 2 types, namely Cyperus rotundus (N1) and Amaranthus spinosus L. (N2). The results showed that (1) There was interaction between the varieties $(\mathrm{V})$ and the weed types $(\mathrm{N})$ in stem diameter parameters and number of tillers, the treatment V4N1 gives the best response to stem diameter $1,31 \mathrm{~cm}$ and 4,25 number of tillers; (2) The treatment of varieties $(V)$ gives affects to stem diameter and number of leaves, the treatment V4 gives the best response 5,38 to number of leaves; (3) Types of thorn spinach weeds can reduce the initial growth of sugarcane.
\end{abstract}

Keywords: Varieties; weed; sugarcane, Saccharum officinarum

\section{Pendahuluan}

Tebu (Saccharum officinarum L.) merupakan tanaman yang memiliki nilai ekonomi tinggi, karena tebu adalah tanaman penghasil gula dan menjadi salah satu komoditas pangan yang banyak dibutuhkan oleh masyarakat Indonesia. Gula di Indonesia banyak dimanfaatkan dalam skala rumah tangga maupun industri. Tingginya permintaan gula nasional tidak sejalan dengan produksinya. Pemerintah berupaya mendorong peningkatan produksi gula supaya dapat memenuhi kebutuhan gula dalam negeri (Yunitasari 2015).

Rendahnya produksi tebu di Indonesia dikarenakan pengetahuan akan teknik budidaya serta pemeliharaannya masih sangat rendah. Salah satu kendala yang mempengaruhi tingkat kuantitas rendemen tebu yaitu adanya pertumbuhan gulma selama periode budidaya.

Gulma mengakibatkan kerugian pada tanaman tebu dikarenakan adanya persaingan nutrisi dan ruang hidup sehingga mengurangi kemampuan tanaman tebu untuk berproduksi. Apabila dibandingkan dengan hama dan patogen, kehadiran gulma menyebabkan 
penurunan hasil tanaman yang cukup signifikan karena gulma bersifat statis dan hidup bersama tanaman utama. Persaingan atau kompetisi yang terjadi antara lain pengambilan air, unsur hara dari tanah, cahaya dan ruang lingkup serta pengeluaran senyawa kimiawi oleh gulma yang beracun bagi tanaman.

Varietas tebu yang tersebar memilki jumlah yang banyak dan dapat dibagi berdasarkan produktivitas, kecepatan kemasakan dan lahan penanaman. Produktivitas diartikan sebagai kemampuan untuk menghasilkan sesuatu atau daya produksi. Produktivitas tebu dapat diukur melalui bobot atau rendemen.

\section{Metode penelitian}

\section{Tempat dan Waktu}

Penelitian dilaksanakan di Sukorejo, Kabupaten Jember. Waktu yang dibutuhkan untuk penelitian ini dimulai pada bulan September 2018 sampai Desember 2018.

\section{Rancangan Percobaan}

Percobaan dilakukan dengan menggunakan Rancangan Acak Kelompok (RAK) faktorial yang terdiri dari dua faktor perlakuan dan 4 kali ulangan. Faktor pertama adalah macam varietas Tebu yang terdiri dari 4 taraf dan faktor kedua yaitu jenis gulma terdiri dari 2 taraf. Faktor pertama varietas tanaman tebu, V1 = Tebu varietas Bululawang, V2 = Tebu varietas HW Merah, V3 = Tebu varietas VMC, V4 $=$ Tebu varietas PS 862. Faktor kedua jenis gulma, N1 = Gulma Teki (Cyperus rotundus L.), N2 = Gulma Bayam duri (Amaranthus spinosus L). Setiap perlakuan dikombinasikan menjadi 8 kombinasi perlakuan yang diulang sebanyak 4 kali. Jumlah keseluruhan perlakuan terdiri dari 32 satuan percobaan. Pada setiap unit perlakuan terdiri dari dua tanaman sehingga jumlah seluruhnya 64 polibag. Apabila terdapat perbedaan yang nyata maka dilakukan uji jarak berganda Duncan dengan taraf kepercayaan 5\%.

\section{Pembuatan Media Tanam}

Media tanam berupa tanah yang sebelumnya telah digemburkan menggunakan cangkul, kemudian dikering anginkan dan diayak untuk menghilangkan kotoran, kerikil atau gulma yang tertinggal didalam tanah. Kemudian media tanah, kompos dan pasir yang telah dicampur dimasukkan kedalam polibag. Kemudian tanah disiram hingga kapasitas lapang yang dicirikan dengan polybag telah mengentaskan air hingga tidak ada lagi air yang keluar dari lubang polibag. Melakukan pembersihan lahan penelitian dari gulma dan sisa tanaman budidaya sebelumnya.

\section{Persiapan bibit Tebu dan Gulma}

Bibit tebu yang berumur 1,5 bulan didapat dengan cara membeli di PG Jatiroto. Bibit tebu yang dipilih memiliki pertumbuhan yang seragam dan tidak terserang hama penyakit tanaman. Selain itu, bibit tanaman tebu yang digunakan harus memiliki pertumbuhan yang tegak, memiliki daun yang segar. Bibit yang telah dipilih kemudian ditanam pada polibag yang telah berisi media. Penanaman bibit dilakukkan dengan cara membuat 1 lubang tanam dengan kedalaman $\pm 5 \mathrm{~cm}$, masing-masing polibag ditanami dengan satu bibit bersama dengan satu bibit gulma dengan jarak $\pm 15 \mathrm{~cm}$.

\section{Penyiraman}

Penyiraman dilakukan sejak awal tanam sebanyak satu kali sehari yakni pada sore hari hingga kapasitas lapang. Pada fase pertumbuhan vegetative, tanaman tebu membutuhkan kondisi air yang terjamin kecukupannya karena pada umur tersebut tanaman tebu megalami pertumbuhan secara horizontal dengan terbentuknya tunas-tunas baru secara bertahap.

\section{Pemupukan dan Penyiangan}

Pemupukan dilakukan pada awal penanaman dengan pemupukan dasar berupa ZA (15gram/polybag) dan SP-36 (12 gram/polybag), semua jenis pupuk dijadikan satu kemudian dibenamkan ke media tanam. Pemupukan kedua dilakukan 45 hari setelah tanam (HST) menggunakan ZA (30 gram/polybag) dan $\mathrm{KCl}$ (30 gram/polybag).

Penyiangan gulma non target dilakukan sesuai kondisi di lapang. Penyiangan dilkaukan secara manual dengan cara mencabut gulma non target yang tumbuh pada polibag. Penyiangan dilakukan untuk menghindari persaingan tempat dan nutrisi antar tanaman tebu dan gulma non target.

\section{Pengendalian hama penyakit}

Pengendalian organisme pengganggu tanaman (OPT) dilakukan dengan cara mekanik dengan memetik daun yang menjadi tempat penyimpanan telurtelur. Daun tersebut kemudian dibuang jauh dari lingkungan budidaya.

\section{Pemanenan}

Pemanenan dilakukan setelah tanaman berumur 90 hari setelah tanaman (HST) dengan cara memisahkan antara tanaman tebu dengan gulma.

\section{Variabel Pengamatan}

Variabel pengamatan meliputi tinggi tanaman, diameter batang, jumlah anakan, jumlah daun, berat basah akar, volume akar, panjang akar, berat basah 
batang, berat basah daun, berat kering akar, berat kering batang, berat kering daun.

\section{Hasil Penelitian}

Berikut rangkuman F-hitung dari semua variabel pengamatan disajikan dalam Tabel 1 berikut:

Tabel 1. Rangkuman F-hitung dari semua parameter pengamatan

\begin{tabular}{|c|c|c|c|c|}
\hline \multirow{2}{*}{\multicolumn{2}{|c|}{ No Parameter }} & \multicolumn{3}{|c|}{ F-Hitung } \\
\hline & & \multirow{2}{*}{$\begin{array}{l}\text { Varietas } \\
0.20 \mathrm{~ns}\end{array}$} & \multirow{2}{*}{$\begin{array}{l}\text { Jenis } \\
\text { Gulma } \\
325^{* *}\end{array}$} & \multirow{2}{*}{$\begin{array}{l}\text { Interaksi } \\
0.66 \mathrm{~ns}\end{array}$} \\
\hline 1 & $\begin{array}{l}\text { Tinggi } \\
\text { Tanaman }\end{array}$ & & & \\
\hline 2 & $\begin{array}{l}\text { Diameter } \\
\text { Batang }\end{array}$ & $12 * *$ & $22.5 * *$ & $4 *$ \\
\hline 3 & Jumlah Anakan & $0.10 \mathrm{~ns}$ & $103.55 * *$ & $3.55 *$ \\
\hline 4 & Jumlah Daun & $4.47 *$ & $27.49 * *$ & $0.84 \mathrm{~ns}$ \\
\hline 5 & Berat Basah Akar & $0.85 \mathrm{~ns}$ & $218.38 * *$ & $0.85 \mathrm{~ns}$ \\
\hline 6 & Volume Akar & $0.14 \mathrm{~ns}$ & $421.5 * *$ & $1.21 \mathrm{~ns}$ \\
\hline 7 & Panjang Akar & $0.59 \mathrm{~ns}$ & $35.39 * *$ & $0.23 \mathrm{~ns}$ \\
\hline$\underline{8}$ & Berat Basah Batang & $0.24 \mathrm{~ns}$ & $37.48 * *$ & $1.99 \mathrm{~ns}$ \\
\hline 9 & Berat Basah Daun & $0.33 \mathrm{~ns}$ & $74.56 * *$ & $1.91 \mathrm{~ns}$ \\
\hline & Berat Kering Akar & $0.97 \mathrm{~ns}$ & $189.64 * *$ & $1.75 \mathrm{~ns}$ \\
\hline & $\begin{array}{l}\text { Berat Kering } \\
\text { Batang }\end{array}$ & $0.44 \mathrm{~ns}$ & $87.74 * *$ & $0.33 \mathrm{~ns}$ \\
\hline 12 & Berat Kering Daun & $1.07 \mathrm{~ns}$ & $147.39 * *$ & $1.04 \mathrm{~ns}$ \\
\hline
\end{tabular}

Keterangan: $\mathrm{ns}=$ berbeda tidak nyata; ${ }^{*}=$ berbeda nyata; ${ }^{* *}=$ berbeda sangat nyata

Hasil percobaan menunjukkan bahwa interaksi antara varietas dan jenis gulma berpengaruh tidak nyata pada seluruh variabel pengamatan kecuali diameter batang dan jumlah anakan. Perlakuan macam varietas tebu memberikan pengaruh sangat nyata pada variabel diameter batang dan pengaruh nyata pada variabel jumlah daun, tetapi pada variabel pengamatan yang lainnya berpengaruh tidak nyata. Perlakuan jenis gulma memberikan pengaruh sangat nyata pada semua variabel pengamatan.

\section{Diameter Batang Tebu}

Berdasarkan hasil pengamatan diameter batang (Gambar 1) menunjukkan bahwa perlakuan V4N1 memberikan respon terbaik pada diameter batang tebu sebesar 1,31 cm, sedangkan hasil terendah diperoleh perlakuan V2N2. Varietas tebu dengan tipe kemasakan awal sampai awal tengah mencapai tingkat kemasakan yang lebih optimal dibandingkan dengan varietas dengan tipe kemasakan tengah hingga tengah lambat (Riajaya et al. 2016).

Gulma Amaranthus spinosus berkompetisi terhadap tanaman tebu berupa cahaya matahari dan unsur hara. Kemampuan gulma berdaun lebar dalam menyerap unsur $\mathrm{N}$ menyebabkan unsur hara tanaman tebu tidak dapat terpenuhi sehingga pertumbuhan tanaman tebu menjadi kurang optimal dengan ditandainya diameter batang yang kecil (Puspitasari et al. 2013).

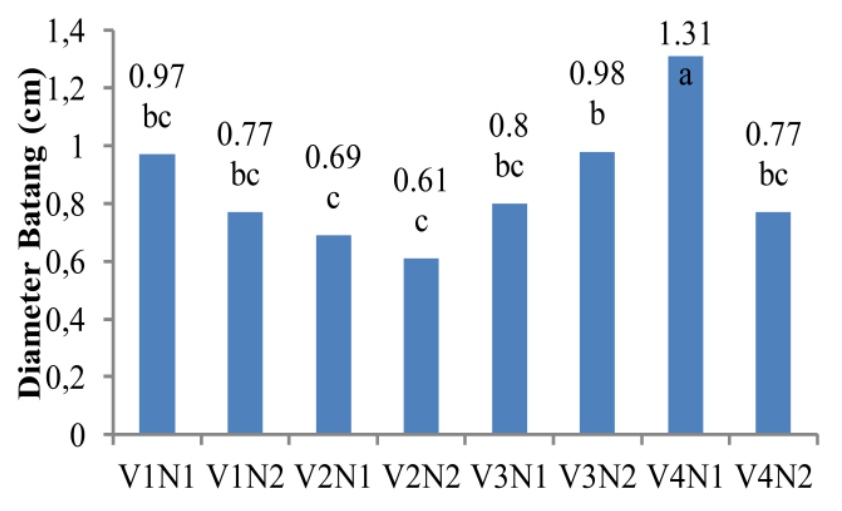

Gambar 1. Pengaruh perlakuan macam varietas dan jenis gulma terhadap diameter batang tebu.

\section{Jumlah Anakan Tebu}

Berdasarkan hasil pengamatan jumlah anakan (Gambar 2) menunjukkan bahwa perlakuan V4N1 menghasilkan jumlah anakan terbanyak sebesar 4,25, sedangkan jumlah anakan terendah diperoleh perlakuan V2N2.

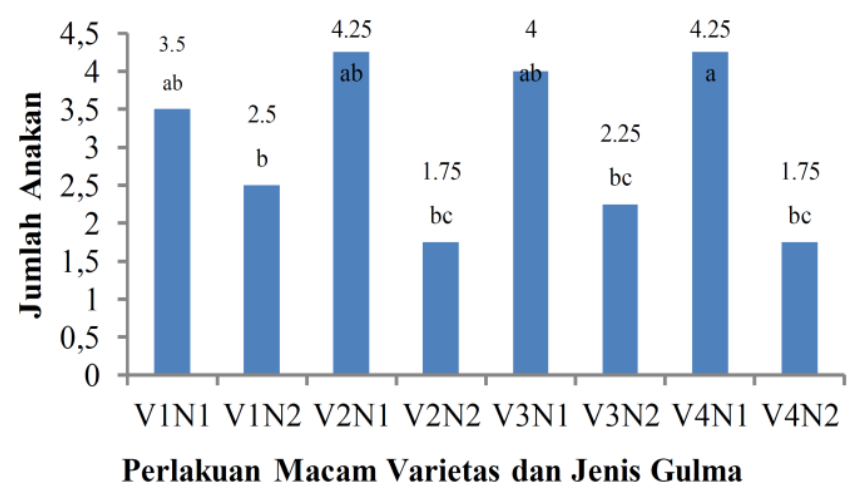

Gambar 2. Pengaruh perlakuan macam varietas dan jenis gulma terhadap jumlah anakan tebu.

Varietas tebu berpengaruh terhadap diameter batang dan jumlah anakan yang dihasilkan. Setiap varietas tebu memiliki kemampuan masing-masing dalam menghasilkan anakan. Adapun selain tipe kemasakan varietas tebu, kondisi lain juga memengaruhi yaitu faktor biotik yang meliputi adaptasi fisologi, populasi tanaman, dan faktor abiotik meliputi air, cahaya matahari, nitrogen, suhu, oksigen dan karbondioksida (Erlina et al. 2017).

\section{Jumlah Daun Tebu}

Berdasarkan hasil pengamatan jumlah anakan (Gambar 3) menunjukkan bahwa perlakuan macam varietas V4 menghasilkan jumlah daun terbanyak 
sebesar 5,38 helai, sedangkan jumlah daun terendah diperoleh perlakuan macam varietas V3.

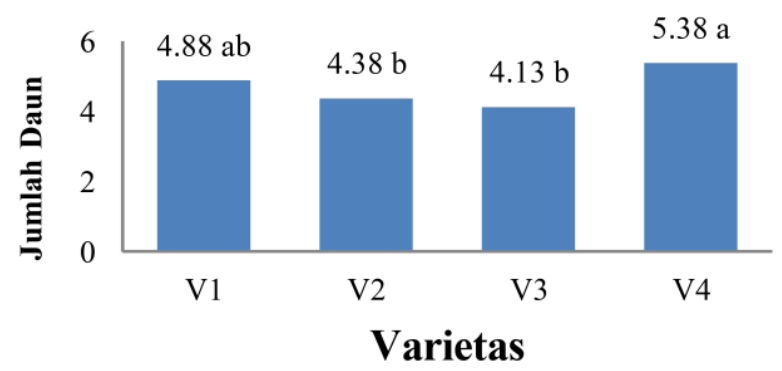

Gambar 3. Pengaruh macam varietas terhadap jumlah daun tebu.

Pertumbuhan jumlah daun tanaman tebu ditentukan oleh faktor genetik yaitu klon dan faktor lingkungan berupa teknik budidaya. Secara umum, klon tebu lebih berpengaruh terhdap pertumbuhan dan perkembangan tanaman tebu dibandingkan dengan metode pembibitan tebu. Produktivitas tebu tergantung dari klon yang berkaitan dengan karakter genetik tanaman (Rokhman et al. 2014).

Berdasarkan hasil pengamatan (Gambar 4) menunjukkan bahwa perlakuan jenis gulma N1 memberikan respon terbaik pada seluruh parameter pengamatan, sedangkan perlakuan jenis gulma N2 memberikan hasil terendah pada seluruh parameter pengamatan. Hal tersebut dikarenakan kemampuan gulma berdaun lebar mampu menyerap unsur hara dan ruang tumbuh lebih besar daripada gulma berdaun sempit. Gulma berdaun lebar layaknya tanaman yang perlu melakuan proses fotosintesis untuk keberlangsungan hidupnya. Nitrogen dalam tanah yang diserap oleh tanaman tebu jumlahnya semakin sedikit karena adanya perebutan unsur hara oleh gulma. Nitrogen berfungsi sebagai pembentuk klorofil yang berperan penting dalam proses fotosintesis (Pramitasari et al. 2016).

Gulma A. spinosus L. memiliki tipe perkembangbiakan generatif, menggunakan bijinya untuk berepro- duksi yang membuat kebutuhan akan air, unsur hara, cahaya matahari dan ruang tumbuh sangat dibutuhkan sehingga persaingan semakin tinggi yang akan menyebabkan pertumbuhan awal tebu kurang optimal (Nasution et al. 2013).

Persaingan antara gulma dengan tanaman yang diusahakan dalam mengambil unsur-unsur hara dan air dari dalam tanah dan penerimaan cahaya matahari untuk proses fotosintesis, sehingga menimbulkan kerugiankerugian dalam produksi baik kualitas maupun kuantitas (Sumanto 2016).

\section{Pembahasan}

Keberadaan gulma pada pertanaman tebu menyebabkan terjadinya persaingan dalam memperebutkan unsur hara, air, udara, cahaya matahari dan ruang hidup. Adanya persaingan tersebut mampu menurunkan kualitas maupu kuantitas tanaman tebu. Keberadaan gulma yang semakin lama bersama tanaman akan menurunkan hasil kompetisi yang terjadi. Konsep kompetisi merupakan suatu bentuk interaksi antara gulma dan tanaman tebu yang saling memperebutkan sarana tumbuh dengan jumlah yang terbatas. Tanaman tebu mudah terpengaruh oleh gulma, terutama pada saat pertumbuhan awal. Beberapa gulma lebih mampu berkompetisi dan menyebabkan kerugian lebih besar pada hasil tanaman pokok. Unsur hara yang paling diperebutkan antara pertanaman dan gulma adalah unsur nitrogen, dan karena nitrogen dibutuhkan dalam jumlah banyak, sehingga lebih cepat habis terpakai. Gulma lebih banyak menyerap unsur hara daripada pertanaman (Arifin 2017).

Kombinasi perlakuan varietas PS 862 (V4) dan jenis gulma teki (N1) menunjukkan respon terbaik pada variabel diameter batang dan jumlah anakan. Perlakuan jenis gulma bayam duri menunjukkan hasil tidak berbeda nyata, hal tersebut diduga persaingan antara tanaman tebu dan gulma teki tidak sebesar persaingan antara tanaman tebu dan gulma bayam duri. Menurut Agropedia (2010) penurunan produk-

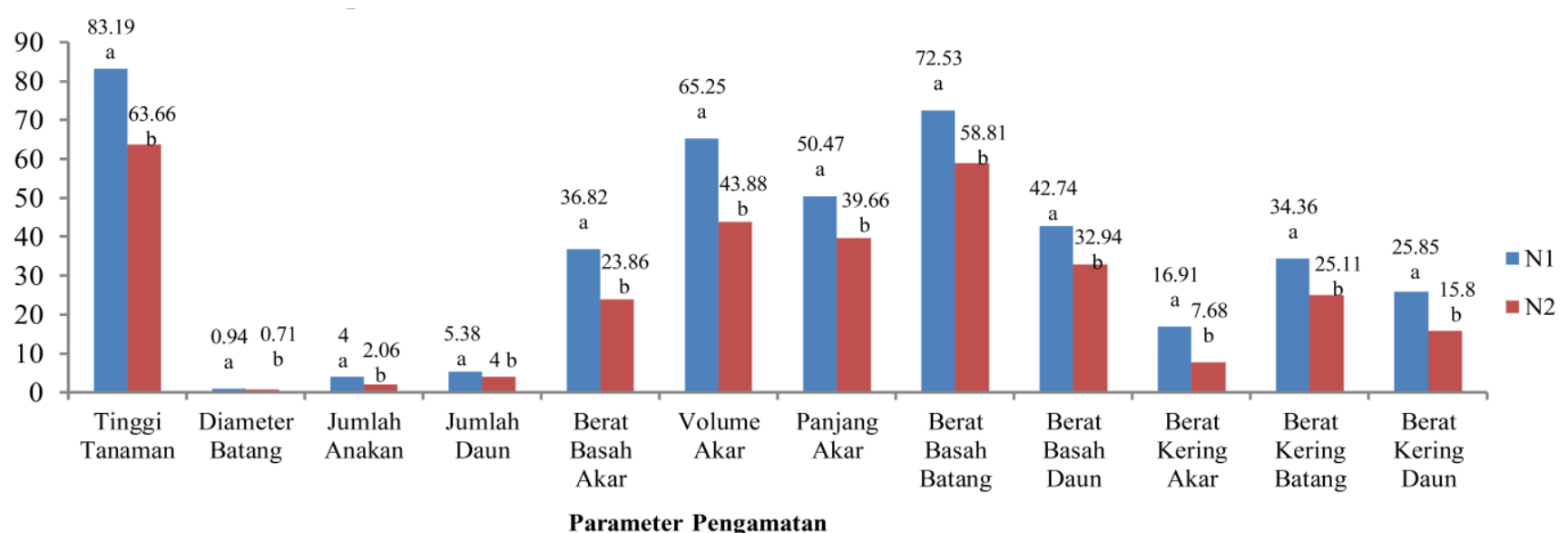

Gambar 4. Pengaruh perlakuan jenis gulma terhadap pertumbuhan awal tanaman tebu. 
tivitas tebu akibat keberadaan gulma dipengaruhi oleh jenis gulma dan agresifitas pertumbuhannya, tercatat dapat mencapi $12-72 \%$. Kemampuan gulma dalam menurunkan produktivitas tebu sangat erat kaitannya dengan persaingan yang terjadi antara tanaman tebu terhadap faktor lingkungan seperti penyerapan cahaya matahari dan serapan air dan unsur hara. Tanaman tebu memiliki kepekaan terhadap keberadaan gulma pada sekitar pertanamannya. Tanaman tebu mulai mengeluarkan tunas-tunas anakannya yakni pada umur 5-8 minggu setelah tanam sampai 10 minggu setelah tanam. Adanya persaingan antara tanaman tebu dengan gulma dalam memperebutkan air, unsur hara dan sinar matahari menyebabkan terganggunya proses pembentukan anakan.

Macam varietas tebu memberikan respon yang berbeda terhadap pertumbuhan awal tanaman tebu. Hasil penelitian menunjukkan bahwa pengaruh macam varietas PS 862 memberikan respon terbaik pada variabel diameter batang dan jumlah daun. Hal tersebut dikarenakan varietas PS 862 merupakan varietas yang memiliki tingkat masak awal. Sedangkan varietas VMC, HW Merah dan Bululawang memiliki tingkat kemasakan awal-tengah, tengah dan tengahlambat. Varietas tebu yang memiliki tingkat masak awal akan mencapai fase kemasakan lebih awal karena lebih sensitf terhadap kondisi cuaca sehingga masak lebih cepat dibanding varietas masak lambat yang akan mencapai kandungan sukrosa maksimum pada waktu akhir panen (Riajaya et al. 2016). Menurut Supriyadi et al. (2018) mengatakan diameter batang tebu dipengaruhi oleh genetik tanaman dan lingkungan tumbuhnya. Perbedaan varietas tebu menyebabkan perbedaan diameter batang yang diperoleh.

Kompetisi antara tanaman tebu dengan gulma dipengaruhi oleh faktor-faktor yang memengaruhi seperti penyerapan cahaya oleh daun, luas tajuk dan tinggi tanaman. Faktor penting berupa air, udara dan cahaya merupakan kompenen yang tak bisa terpisahkan oleh pertumbuhan suatu gulma. Terpenuhinya faktor tumbuh maka akan semakin baik pertumbuhan gulma dalam pekembangbiakan maupun dalam menguasai area (Sari et al. 2016).

Daun tebu akan muncul dan berkembang selama periode antara satu dan tingga minggu. Apabila jumlah daun banyak maka kemampuan melakukan fotosintesis lebih tinggi dibandingkan dengan jumlah daun yang lebih sedikit (Raharjo et al. 2017). Pertumbuhan organ tanaman tebu yang tidak optimal mengindikasikan bahwa pertumbuhan akar juga kurang optimal. Semakin baik pertumbuhan akar, maka kemampuan akar dalam menjangkau pasokan nutrisi tanaman akan semakin baik dan kebutuhan tanaman menjadi terpenuhi sehingga pertumbuhannya akan optimal (Hartatik et al. 2015).

Perebutan ruang tumbuh didalam tanah menjadi faktor penghambat dalam proses pemanjangan akar tanaman tebu. Pertumbuhan akar yang tidak optimal menyebabkan tanaman tebu kalah bersaing dengan gulma bayam duri sehingga pertumbuhan tebu menjadi kurang optimal. Sifat tanaman apabila terjadi keku- rangan air, maka tanaman akan memanjangkan akarnya sampai ke lapisan tanah yang memiliki ketersediaan air yang cukup sehingga tanaman dapat bertahan hidup. Tanaman yang memiliki perakaran yang panjang akan memiliki kemampuan yang lebih baik dalam mengabsorbsi air dibandingkan dengan tanaman berakar pendek (Ai dan Torey 2013). Menurut Rahman et al. (2017) jumlah akar yang terbentuk akan menentukan volume akar. Banyaknya jumlah akar yang terbentuk maka kemampuan akar menyerap unsur hara semakin tinggi dan hasil dari fotosintesis dapat dialokasikan keseluruh bagian tanaman termasuk untuk pertumbuhan akar. Banyaknya akar yang tumbuh memungkinkan tanaman untuk menyerap air dan unsur hara di dalam tanah dalam jumlah yang cukup banyak, sehinga tanaman dapat tumbuh dengan baik. Tanaman yang kebutuhan unsur haranya terpenuhi dapat menunjang penambahan luas daun, penambahan volume akar, penambahan bobot segar total dan penambahan bobot kering total (Adinugraha et al. 2016). Kompetisi yang terjadi menyebabkan fotosintat yang dihasilkan tidak optimal sehingga pendistribusian ke bagian tanaman menjadi kurang. Hasil fotosintat yang optimal akan memacu aktifitas pemanjangan sel dan merangsang tumbuhnya batang. Semakin tinggi fotosintat yang dihasilkan oleh tanaman dari hasil fotosintesis, maka akan meningkatkan bobot segar tanaman (Nugroho dan Eko 2017).

Berdasarkan hasil penelitian Kompetisi Beberapa Jenis Gulma Terhadap Pertumbuhan Awal Beberapa Varietas Tanaman Tebu (Saccharum officinarum L.) dapat diambil kesimpulan yaitu terdapat interaksi antara macam varietas $(\mathrm{V})$ dan jenis gulma $(\mathrm{N})$ yang berpengaruh nyata terhadap parameter diameter batang dan jumlah anakan, dimana perlakuan V4N1 memberikan respon terbaik $1,31 \mathrm{~cm}$ pada diameter batang dan 4,25 pada jumlah anakan. Perlakuan varietas (V) berpengaruh nyata terhadap diameter batang dan jumlah daun, dimana perlakuan V4 memebrikan respon terbaik 5,38 pada parameter jumlah daun. Jenis gulma bayam duri mampu menekan pertumbuhan awal tanaman tebu.

\section{Pernyataan tidak ada konfik kepentingan}

Semua penulis artikel ini menyatakaan bahwa tidak ada konflik kepentingan terkait penelitian dan hasil penelitian ini.

\section{DAFTAR PUSTAKA}

Adinugraha I, Nugroho A, Wicaksono KP. 2016. Pengaruh asal bibit bud chip (Saccharum officinarum L.). Produksi Tanaman 4 (6): 468-477.

Agropedia. 2010. Weeds Infestation in Sugarcane. Kanpur. India.

Ai NS, Torey P. 2013. Karakter morfologi akar sebagai indikator kekurangan air pada tanaman. Jurnal Bioslogos 3 (1): 31-39. 
Arifin Z. 2017. Pengaruh sistem pengendalian gulma terhadap pertumbuhan awal tanaman tebu (Saccharum officinarum L.). Folium 1(1): 59-70.

Erlina Y, Wicaksono KP, Barunawati N. 2017. Studi pertumbuhan dua varietas tebu (Saccharum officinarum L.) dengan jenis bahan tanam berbeda. Produksi Tanaman 5 (1): 33-38.

Hartatik D, Wijaya KA, Bowo C. 2015. Respon pertumbuhan tanaman tebu varietas Bululawang dan Hari Widodo dengan pemberian silika. [Skripsi] Universitas Jember, Jember.

Nasution KH, Islami T, Sebayang HT. 2013. Pengaruh dosis pupuk anorganik dan pegendalian gulma pada pertumbuhan vegetatif tanaman tebu (Saccharum officinarum L.) varietas PS 881. Produksi Tanaman 1 (4): 299-307.

Nugroho PS, Widaryanto E. 2017. Pengaruh umur bibit single bud planting pada dosis pupuk $\mathrm{n}$ terhadap pertumbuhan dan hasil tanaman tebu (Saccharum officinarum L.) sejak umur 6 bulan. Produksi Tanaman 5 (100): 1645-1652.

Pramitasari HE, Wardiyati T, Nawawi M. 2016. Pengaruh dosis pupuk nitrogen dan tingkat kepadatan tanaman terhadap pertumbuhan dan hasil tanaman Kailan (Brassica oleraceae L.). Produksi Tanaman 4 (1): 49-56.

Puspitasari K, Sebayang HT, Guritno B. 2013. Pengaruh aplikasi herbisida ametrin dan 2,4-D dalam mengendalikan gulma tanaman tebu (Saccharum officinarum L.). Produksi Tanaman 1 (2): 72-80.

Raharjo EB, Tyasmoro SY, Sebayang HT. 2017. Pengaruh pengendalian gulma pada pertumbuhan vegetatif dua jenis bibit tanaman tebu (Saccharum officinarum L.). Produksi Tanaman 5 (4): 641-646.
Rahman M, Karno, Kristanto BA. 2017. Pemanfaatan tanaman kelor (Moringa oleifera) sebagai hormon tumbuh pada pembiitan tanaman tebu (Saccharum officinarum L.). Agro Complex 1 (3): 94-100. DOI: 10.14710/joac.1.3.94-100

Riajaya PD, Kadarwati FT. 2016. Kesesuaian tipe kemasakan varietas tebu pada tipologi lahan bertekstur berat, tadah hujan dan drainase lancar. Buletin Tanaman Tembakau, Serat dan Minyak Industri 8 (2): 85-97.

Rokhman H, Taryono, Supriyanta. 2014. Jumlah anakan dan rendemen enam klon tebu (Saccharum officinarum L.) asal bibit bagal, mata ruas tunggal, dan tunas tunggal. Vegetalika 3 (3): 89-96.

Sari DM, Sembodo DRJ, Hidayat KF. 2016. Pengaruh jenis dan tingkat kerapatan gulma terhadap pertumbuhan awal tanaman ubikayu (Manihot esculenta Crantz) klon UJ-5 (Kasetsart). Agrotek Tropika 4 (1): 1-6. DOI: 10.23960/jat.v4i1.1869

Sumanto. 2016. Pertumbuhan dan produksi bibit tebu G3 kultur jaringan varietas PS 862 pada perlakuan jarak tanam dan $\begin{array}{llll}\text { pupuk kandang. Littri } 22 & \text { (2): 99-106. DOI: }\end{array}$ 10.21082/littri.v22n2.2016.99-10

Supriyadi ADK, Djumali. 2018. Pertumbuhan, produktivitas dan hasil hablur klon tebu masak awal tengah di tanah inceptisol. Agron Indonesia $46 \quad$ (2): 208-214. DOI: 10.24831/jai.v46i2.17088

Yunitasari, D. 2015. Model Pengembangan Agroindustri Gula Tebu Sebagai Upaya Peningkatan Perekonomian Wilayah Di Jawa Timur. [Tesis] Institut Pertanian Bogor, Bogor. 